\title{
PENILAIAN KOORDINASI ANTARUNIT KERJA DI RUMAH SAKIT BERDASARKAN HIGH PERFORMANCE WORK PRACTICES
}

\author{
ASSESSMENT OF COORDINATION BETWEEN UNITS IN HOSPITAL BY HIGH PERFORMANCE WORK \\ PRACTICES
}

Intan Permata Sari, Ratna Dwi Wulandari

Fakultas Kesehatan Masyarakat, Universitas Airlangga, Surabaya

Email :intan-p-s-11@fkm.unair.ac.id

\begin{abstract}
The survey about coordination in hospital showed that the coordinaton between units have low score including the lack of communication and problem solving between units. The objectives of this study is to describe coordination in hospital considered by high performance practices that consist of 5 items : selection for cross-functional teamwork, rewards for cross-functional teamwork, cross-functional teamwork conflict resolution, cross-functional meetings, and cross-functional boundary spanner. This research is descriptive study using cross sectional design. Samples or respondents are 16, selected using purposive sampling according to the units which their function and job still related with the medical service in the hospital. The result showed that there are a specific criteria to select their employee. The most responden said that education level is the most important criteria for the selection. There is a reward for the best employee those are trophy and some money given to the best employee and the best group of the months. There is conflict resolution through the meeting with the supervisor and director to discuss their problems. There is functional meeting that is weekly report, and there is boundary spanner to coordinated with the other unit if they have problems. This study conclude that coordination in hospital can complete four items of performance work practice, but aspect cross-functional meetings still not working properly. Therefore, it needs to be repaired because this meeting is important to discuss about development of the medical service in this hospital.
\end{abstract}

Keywords :Coordination, high performance work practices, medical service

\section{PENDAHULUAN}

Organisasi merupakan suatu kumpulan unit

yang bekerja bersama-sama untuk mencapai tujuan yang diinginkan.Setiap unit ini memiliki tugas dan fungsi masing-masing yang saling terhubung untuk mencapai tujuan organisasi.Penghubung antarunit supaya dapat berfungsi secara berkesinambungan adalah koordinasi.Koordinasi merupakan salah satu fungsi manajemen yang harus berjalan dalam suatu organisasi.Sebagai salah satu fungsi manajemen, koordinasi memiliki peran sebagai pengikat, penyeimbang, dan penyelaras semua aktifitas dan usaha dari setiap unit.

Koordinasi penting dalam suatu koordinasi untuk mencegah terjadinya kekacauan, percecokan, dan kekembaran maupun kekosongan pekerjaan.Koordinasi juga penting agar para pekerja dan pekerjaannya diselaraskan serta diarahkan untuk pencapaian tujuan organisasi.Koordinasi juga berfungsi supaya sarana dan prasaran dimanfaatkan untuk mencapai tujuan bersama supaya semua unsur manajemen dan pekerjaan masing-masing individu dapat membantu tercapainya tujuan organsasi.Dan supaya semua tugas, kegiatan, dan pekerjaan terintegrasi kepada sasaran yang diinginkan.

Rumah sakit juga merupakan suatu organisasi yang memiliki banyak unit yang bekerja untuk mencapai suatu tujuan.Salah satu tujuan rumah sakit yaitu memberikan pelayanan kesehatan yang terbaik bagi masyarakat. Untuk dapat mencapai tujuan 
tersebut sebuah rumah sakit perlu memperhatikan segala aspek yang ada, termasuk bagaimana bentuk manajemen yang mengatur segala proses yang ada di rumah sakit. Fungsi manajemen harus diupayakan untuk dapat berjalan sehingga dapat menghasilkan suatu manajemen yang baik.

Salah satu fungsi manajemen ini adalah koordinasi antar unit kerja yang ada di rumah sakit.Koordinasi merupakan pusat utama dalam suatu manajemen di suatu organisasi. Kuat lemah koordinasi mempengaruhi keberhasilan proses manajemen organisasi tersebut. Dengan berjalannya fungsi koordinasi dengan baik antarunit kerja di rumah sakit, maka pelaksanaan pelayanan medik di rumah sakit juga akan lebih maksimal.

Permasalahan yang dihadapi rumah sakit ini adalah lemahnya koordinasi antarunit. Berdasarkan penelitian yang dilakukan oleh pihak rumah sakit diketahui bahwa nilai rata-rata koordinasi yaitu 2,33 sedangkan nilai tertinggi 5 . Nilai rata-rata tersebut masih terpaut jauh dengan nilai patokan tertinggi dari koordinasi. Penelitian ini bertujuan untuk menggambarkan koordinasi di rumah sakit berdasarkan high performance work practices. Hasil penelitian ini diharapkan dapat menjadi gambaran bagi organisasi tentang koordinasi yang ada, sehingga dapat dibuat rekomendasi untuk memperbaiki fungsi koordinasi.

\section{PUSTAKA}

\section{Rumah Sakit}

Pengertian rumah sakit menurut UU RI No.44 Tahun 2009 tentang Rumah Sakit adalah institusi pelayanan kesehatan yang menyelenggarakan pelayanan kesehatan perorangan secara paripurina yang menyediakan pelayanan rawat inap, rawat jalan, dan gawat darurat. Sedangkan Kepmenkes RI Nomor 129 tahun 2008 menyebutkan rumah sakit sebagai sarana kesehatan yang menyelenggarakan pelayanan kesehatan perorangan meliputi pelayanan promotif, preventif, kuratif, dan rehabilitatif yang menyediakan pelayanan rawat inap, rawat jalan, dan gawat darurat.

Definisi pelayanan medik menurut Depkes RI (2009) adalah setiap upaya yang diselenggarakan sendiri atau bersama-sama dalam suatu organisasi untuk memelihara dan meningkatkan kesehatan, mencegah, dan menyembuhkan penyakit serta memulihkan kesehatan perorangan, keluarga, atau masyarakat.Sesuai dengan penjelasan di atas, dapat diketahui bahwa bentuk dan jenis pelayanan ditentukan oleh pengorganisasian pelayanan dan ruang lingkup kegiatan.Apakah dilaksanakan secara sendiri atau secara bersama-sama dalam suatu organsasi, dan apakah hanya mencakup kegiatan pemelihaan kesehatan, pencegahan penyakit, penyembuhan penyakit, pemulihan kesehatan atau kombinasi dari hal tersebut. 
Rumah sakit merupakan suatu organisasi yang didalamnya juga memiliki banyak unit yang bekerja bersama untuk mencapai tujuan organisasi.Salah satu tujuan dari rumah sakit adalah mampu memberikan pelayanan medik yang maksimal kepada masyarakat.Fungsi manajemen harus berjalan dengan baik untuk dapat mencapai tujuan organisasi.Salah satu fungsi manajemen ini yaitu koordinasi.Untuk dapat mencapai tujuan ini, fungsi koordinasi harus berjalan.Koordinasi ini berfungsi untuk mengintegrasikan tugas antarunit.

\section{Koordinasi}

Koordinasi merupakan suatu pengatur beragam elemen kedalam suatu pengoperasian yang terpadu dan harmonis. Kesuksesan koordinasi akan menciptakan keharmonisan dan keselarasan seluruh kegiatan untuk mencapai tujuan yang diharapkan, sehingga beban tiap bagian menjadi serasi, selaras, dan seimbang. Sebagai salah satu fungsi manajemen koordinasi merupakan fungsi pengikat, penyeimbang dan penyelaras semua aktifitas dan usaha, maka dapat disimpulkan bahwa setiap fungsi manajemen pasti memerlukan fungsi koordinasi. Koordinasi dapat dijelaskan melalui pembahasan teori relational coordination dan high performance work practices.

Relational coordination merupakan sebuah teori yang timbul untuk memahami hubungan dinamis dari koordinasi kerja. Secara khusus relational coordination diartikan sebagai proses yang saling mendukung interaksi antara komunikasi dan hubungan dengan maksud untuk mencapai kesatuan tugas
(Gittel 2010). Berdasarkan teori ini, ada tiga hubungan yang dibutuhkan untuk terjadinya proses koordinasi, yaitu penyamaan atau pembagian tujuan (shared goal), pembagian pengetahuan (shared knowledge), dan hubungan saling menghargai (mutual respect).

Menurut teori relational coordination, koordinasi akan lebih efektif jika dilakukan melalui komunikasi yang frekuen dan berkualitas, serta melalui kualitas hubungan yang tinggi antar partisipan atau pekerja dalam organisasi. Komunikasi yang berkualitas tinggi (yang frekuen, akurat dan tepat waktu serta problem-solving communication) akan mempengaruhi hubungan yang berkualitas tinggi (meliputi aspek shared goals, shared knowledge dan mutual respect) begitu pula sebaliknya.

\section{High Performance Work Practices}

Seperti yang telah disebutkan diatas, menurut Gittel (2010) koordinasi dapat dijelaskan melalui pembahasan teori relational coordination dan high performance work practices. Pada bagian ini akan dijelaskan tentang high performance work practices.

High performance work practices dapat meningkatkan performa organisasi melalui penguatan hubungan antar anggota yang berbeda dalam sebuah organisasi. Performa organisasi dapat dilihat dari produktivitas kerja, efisiensi outcome, kualitas produk, dan performa sistem keuangan organisasi (Gittel, 2010). Performa organisasi dipengaruhi oleh bagaimana cara yang digunakan untuk mangatur pegawai atau anggota organisasi. Performa kerja dalam organisasi juga dapat diraih dengan 
mengadopsi praktik kerja yang memungkinkan anggota organisasi untuk mampu mengenal dan meningkatkan kemampuannya dalam menciptakan sebuah nilai.

High performance work practices ini juga mempengaruhi tujuh dimensi relational coordination. Tipe dari sistem penampilan kerja (performance work system) mempengaruhi pengetahuan dan skill serta komitmen pekerja. Disamping itu juga dapat mempengaruhi perubahan kualitas dan efisiensi dari penampilan organisasi. Terdapat lima komponen untuk melihat praktik penampilan kerja yang tinggi. Kelima dimensi tersebut yaitu selection for cross-functional teamwork (pemilihan antar kelompok kerja fungsional), rewards for cross-functional teamwork (penghargaan untuk antar kelompok kerja fungsional), cross-functional teamwork conflict resolution (resolusi konflik antar kelompok kerja fungsional), crossfunctional meetings (pertemuan antar kelompok kerja fungsional), dan cross-functional boundary spanner (kontrol rentang antar kelompok kerja fungsional).

\section{Selection for cross-functional teamwork} adalah adanya adanya kriteria khusus yang telah ditentukan oleh organisasi untuk merekrut pekerja.Setiap organisasi pasti memiliki kriteria yang sesuai dengan kebutuhan setiap organisasi.Melalui kriteria seleksi staf yang sederhana seperti kompetensi (skill), personality, dankemampuan bekerja sama dapat mempengaruhi kinerja organisasi. Dalam konteks pekerjaan yang memiliki tingkat ketergantungan tugas yang tinggi, kriteria seleksi staf antarunit mempunyai pengaruh yang signifikan terhadap penguatan aspek saling menghargai (mutual respect) pada dimensi relational coordination.

Rewards for cross-functional teamwork adalah adanya rewards dapat memberikan motivasi bagi pegawai untuk meningkatkan performa kerja. Reward bisa dalam bentuk yang beragam, mulai dari material seperti hadiah barang atau uang, hingga nonmaterial seperti pengakuan, apresiasi, pengangkatan status pekerjaaan, pelatihan, dan sebagainya.

Cross-functional teamwork conflict resolution adalah sarana penyelesaian apabila terjadi konfilik atau masalah dalam suatu organisasi. Konflik antarunit terjadi saat ketergantungan tugas antarunit sangat tinggi atau perbedaan tugas antarindividu atau antarunit sangat tinggi.Konflik antarunit dapat memberikan dampak postif bila mampu dicapai sebuah resolusi. Conflict resolution dapat memberikan peran yang konstruktif dengan menyediakan sebuah cara untuk mengartikulasikan dan mengakomodir berbagai sudut pandang. Setiap sudut pandang tersebut berguna untuk menambah value terhadap proses kerja.

Cross-functional meetings adalah pertemuan antarunit yang merupakan mekanisme koordinasi yang lebih ampuh karena menghadirkan semua pihak yang terkait secara langsung sehingga dapat dihasilkan informasi yang relevan.Face-to-face interactions diakui sebagai cara yang efektif untuk mengukur efektivitas komunikasi antarunit. Dalam teori relational 
coordination pertemuan antarunit dapat memperkuat dimensi shared goals dan shared knowledge.

Cross-functional boundary spanner adalah orang yang ditunjuk sebagai pengontrol rentang atau koordinator memiliki fungsi mengintegrasikan berbagai tugas dan proses antarunit kerja yang berbeda. Koordinator memiliki peran penting untuk mengalirkan infromasi baru yang dibutuhkan oleh setiap unit kerja terkait. Dalam teori relational coordination adanya koordinator dapat memperkuat dimensi shared knowledge (Gittel, et al.,2010).

\section{METODE}

Penelitian ini merupakan penelitian deskriptif.Apabila dilihat dari waktu pelaksanaan, penelitian ini termasuk dalam penelitian cross sectional. Unit analisis dalam penelitian ini dipilih berdasarkan purposive sampling, yakni 16 unit kerja yang tugas dan fungsi dalam pekerjaannya berhubungan dengan pelaksanaan pelayanan medik. Responden berjumlah 16 yang merupakan koordinator dari 16 unit yang telah dipilih secara purposive.

Penelitian dilaksanakan pada bulan Juli 2015

Penelitian ini dilakukan melalui kuesioner yang diisi mandiri oleh responden.Kuesioner ini terdiri dari 5 pertanyaan berdasarkan 5 dimensiperformance work practices, yakni aspek selection for cross-functional teamwork, rewards for cross-functional teamwork, cross-functional teamwork conflict resolution, crossfunctional meetings, dan cross-functional boundary spanner.
Analisis hasil kuesioner dilakukan dengan menghitung persentase jawaban dari responden dalam kategori tidak ada, kadang ada, dan selalu ada. Apabila responden menjawab kadang ada dan selalu ada, maka responden menyebutkan apa saja selection for cross-functional teamwork, rewards for crossfunctional teamwork, cross-functional teamwork conflict resolution, cross-functional meetings, dan cross-functional boundary spanner yang ada di rumah sakit tersebut

Analisis data berikutnya dilakukan berdasarkan jawaban terbuka untuk melihat jawaban terbanyak menurut responden.Setiap dimensi dari high performance work practices dihitung persentasenya untuk melihat jawaban terbanyak dari responden. Dari analisis ini dapat diketahui pelaksanaan koordinasi di rumah sakit ini.

\section{HASIL \& PEMBAHASAN}

\section{Analisis High Performance Work Practices}

Berdasarkan Tabel 1 dapat diketahui bahwa paling banyak responden menjawab selalu ada kriteria atau pertimbangan tertentu dalam proses seleksi staf terkait pelaksanaan tugas dalam hal pelayanan medik di setiap unit kerjanya yakni sebanyak $68,75 \%$ responden, sedangkan paling rendah menjawab tidak ada yakni 6,25\% responden.

Dalam hal pemberian reward paling banyak menjawab ada reward untuk individu dan tim yakni sebanyak $50 \%$ responden dan paling rendah menjawab ada reward hanya untuk individu sebanyak 
$12,5 \%$ responden. Dalam hal ketersediaan akses penyelesaian masalah antarunit kerja diakui selalu ada akses sebayak $50 \%$ responden dan menjawab kadang ada akses sebanyak $50 \%$ responden, tidak ada satu pun responden yang menjawab tidak ada akses dalam penyelesaian masalah. Tabel 1 Analisis High Performance Work Practices terkait Pelaksanaan Pelayanan Medik di Rumah Sakit

Pertemuan berkala antarunit kerja terkait dalam pelayanan medik diakui kadang ada oleh sebanyak $50 \%$ responden, sedangkan $25 \%$ responden menjawab tidak ada pertemuan berkala dan $25 \%$ responden menjawab selalu ada pertemuan berkala antarunit kerja untuk membahas masalah yang terjadi dalam koordinasi terkait pelaksanaan pelayanan medik. Pertemuan berkala ini merupakan sarana bertukar informasi terkait pelaksanaan pelayanan medik.

Sebagian besar responden menjawab selalu ada koordinator antarunit kerja terkait pelayanan medik yakni sebanyak $62,5 \%$, sedangkan $18,75 \%$ responden menyatakan bahwa tidak ada koordinator dan $18,75 \%$ responden menyatakan kadang ada koordinatoor antarunit kerja yang bertanggung jawab berlangsungnya koordinasi terkait pelaksanaan pelayanan medik dengan baik. Koordinator ini merupakan wakil dari setiap unit yang bertanggung jawab menjadi penengah apabila terjadi suatu permasalah. Uraian dari kelima dimensi high performance work practices dijelaskan sebagai berikut.

\section{Uraian Setiap Aspek High Performance Work Practices \\ Kriteria penilaian staf yang utama dalam} pelaksanaan pelayanan medik di rumah sakit adalah tingkat pendidikan petugas sesuai kebutuhan unit yakni sebesar 20,6\% seperti yang tercantum dalam Tabel 1. Selain itu responden juga menyatakan bahwa kriteria penilaian staf lainnya yaitu seseorang yang bertanggung jawab dengan tugasnya, mempunyai pengalaman kerja, memiliki pengetahuan dan keterampilan yang mumpuni dalam bidangnya, mampu berkomunikasi dengan baik, berperilaku baik dan ramah, jujur serta mampu bekerja sama dalam tim. Dari Tabel 1 dapat diketahui bahwa dalam pemilihan karyawan atau petugas di rumah sakit ini, kriteria yang paling diperhatikan adalah tingkat pendidikan yang sesuai dengan kebutuhan setiap unit.

Tabel 1 Selection for Cross-functional TeamworkTerkait Pelaksanaan Pelayanan Medik di Rumah Sakit

\begin{tabular}{lcc}
\hline \multicolumn{1}{c}{ Selection for cross-functional teamwork } & Frekuensi (n) & Persentase (\%) \\
\hline Tingkat pendidikan sesuai kebutuhan unit & 6 & 20,6 \\
Tanggung jawab dengan tugasnya & 5 & 17,2 \\
$\begin{array}{l}\text { Mempunyai pengalaman kerja } \\
\text { Memiliki pengetahuan dan keterampilan }\end{array}$ & 5 & 17,2 \\
mumpuni dalam bidangnya & 3 & 10,3 \\
Mampu berkomunikasi dengan baik & 3 & 10,3 \\
Berperilaku baik dan ramah & 3 & 10,3 \\
Jujur & 2 & 6,8 \\
Mampu bekerja sama dalam tim & 2 & 6,8 \\
\hline
\end{tabular}


Tabel 2 Rewards for Cross-functional Teamwork bagi Karyawan Terkait Pelaksanaan Pelayanan Medik di Rumah Sakit

\begin{tabular}{|c|c|c|}
\hline $\begin{array}{c}\text { Rewards for cross-functional } \\
\text { teamwork }\end{array}$ & Frekuensi (n) & Persentase (\%) \\
\hline $\begin{array}{l}\text { Trophy dan uang untuk the best } \\
\text { employee }\end{array}$ & 8 & 42,1 \\
\hline Trophy dan uang untuk the best team & 7 & 36,8 \\
\hline Pujian & 3 & 15,7 \\
\hline Nilai yang baik dalam penilaian kinerja & 1 & 5,2 \\
\hline
\end{tabular}

Tabel 3 Cross-functional Teamwork Conflict Resolution Terkait Pelaksanaan Pelayanan Medik di Rumah Sakit

\begin{tabular}{lcc}
\hline Cross-functional teamwork conflict resolution & Frekuensi (n) & Persentase (\%) \\
\hline Forum dengan supervisor dan direksi & 14 & 82,3 \\
Menegur secara langsung & 3 & 17,6 \\
\hline
\end{tabular}

Reward untuk karyawan berprestasi adalah mendapatkan trophy dan uang untuk kategori the best employee of the month. Hal ini ditunjukkan dengan $42,1 \%$ responden memiliki jawaban yang samaRewarduntuk unit kerja terbaik adalah trophy dan uang untuk kategori the best team of the month, sebanyak $36,8 \%$ responden memiliki pendapat yang sama.

Sebanyak $15,7 \%$ responden berpendapat bahwa bentuk rewardlainnya untuk karyawan yang dapat menjalankan tugasnya dengan baik adalah pemberian ujian, dan 5,2\% responden berpendapat bahwa reward yang didapat adalah pemberian nilai yang baik dalam penilaian kinerja.Berdasarkan Tabel 4 dapat diketahui apabila terdapat masalah antarunit kerja, forum atau diskusi dengan supervisor dan direksi merupakan bentuk akses penyelesaian masalah yang

Tabel 4 Cross-functional Meetings Terkait Pelaksanaan Pelayanan Medik di Rumah Sakit

\begin{tabular}{lcc}
\hline \multicolumn{1}{c}{ Cross-functional meetings } & Frekuensi (n) & Persentase (\%) \\
\hline Weekly report & 8 & 66,6 \\
Pertemuan yang tidak terjadwal (insidental) & 4 & 33,3 \\
\hline
\end{tabular}

paling banyak dilakukan antarunit kerja dengan persentase sebesar $82,3 \%$. Menurut responden forum dengan supervisor dan direksi ini merupakan media pertemuan yang yang merupakan sarana untuk mencari solusi bersama apabila terjadi masalah dalam pelaksanaan pelayanan medik.

Weekly report merupakan cross-functional meetings di rumah sakit. Sebanyak $66,6 \%$ responden menjawab dengan pendapat yang sama. Weekly reportmerupakan pertemuan yang diadakan satu kali dalam seminggu untuk melaporkan seluruh proses dan capaian pelaksanaan pelayanan medik. Semua unit diwajibkan untuk menghadiri pertemuan ini.Weekly report juga merupakan sarana untuk mendapatkan informasi apabila terjadi perubahan kebijakan di rumah sakit. 
Tabel 5 Cross-functional Boundary SpannerTerkait Pelaksanaan Pelayanan Medik di Rumah Sakit

\begin{tabular}{lcc}
\hline \multicolumn{1}{c}{ Cross-functional Boundary Spanner } & Frekuensi (n) & Persentase (\%) \\
\hline Supervisor tiap unit & 6 & 35,2 \\
Wakil direktur pelayanan medik & 4 & 23,5 \\
Manajer & 3 & 17,7 \\
Kepala instalasi & 2 & 11,8 \\
Penanggung jawab disetiap shift & 1 & 5,9 \\
Koordinator ICU dan IGD & 1 & 5,9
\end{tabular}

Cross-fuctional boundary spanner atau koordinator antarunit adalah supervisor tiap unit. Hal ini ditunjukkan dengan $35,2 \%$ responden memiliki pendapat yang sama. Setiap unit di rumah sakit ini memiliki supervisor yang bertanggung jawab terhadap keberhasilan setiap unit.Supervisor ini merupakan wakil dari unit yang salah satu tugasnya adalah sebagai koordinator apabila terjadi konflik antarunit di rumah sakit.

Dapat diketahui $23,5 \%$ responden lainnya berpendapat bahwa wakil direktur pelayanan medik merupakan koordinator yang bertanggung jawab untuk menyelesaikan masalah yang timbul terkait pelaksanaan pelayanan medik. Responden lain berpendapat bahwa manajer, kepala instalasi, penanggung jawab setiap shift, dan koordinator ICU dan IGD merupakan koordinator yang bertanggung jawab untuk menyelesaikan masalah yang timbul terkait pelaksanaan pelayanan medik.

\section{SIMPULAN}

Berdasarkan hasil penelitian dapat disimpulkan bahwa koordinasi terkait pelaksanaan pelayanan medik di rumah sakit dapat digambarkan dengan high performance work practices dengan melihat lima dimensi yang ada. Tingkat pendidikan sesuai dengan kebutuhan unit merupakan kriteria paling dominan untuk selection for cross-functional teamwork.Selalu ada reward berupa trophy dan uang untuk karyawan terbaik dan unit terbaik. Ini merupakan pemenuhan dimensi rewards for cross-functional teamwork. Sebesar 50\% responden menjawab kadang ada dan $50 \%$ responden menjawab selalu ada akses penyelesaian masalah antarunit kerja, akses ini berupa forum dengan supervisor dan direksi untuk menyelesaikan permasalahan. Kadang ada pertemuan berkala antarunit kerja dalam bentuk weekly report yang diadakan satu kali dalam seminggu untuk membahas perkembangan pelaksanaan pelayanan medik dan informasi apabila ada perubahan kebijakan terkait pelayanan medik.Dapat diketahui juga bahwa selalu ada koordinator antarunit kerja yakni supervisor dari masing-masing unit.

Berdasarkan hasil penelitian ini dapat diketahui gambaran koordinasi di rumah sakit sudah memenuhi high performance work practice ditunjukkan dengan jawaban responden yang menjawab selalu ada aspek kriteria seleksi staf, reward bagi petugas, akses penyelesaian masalah antarunit kerja dan adanya koordinator antarunit kerja. Aspek pertemuan 
berkala antarunit kerja mayoritas responden menjawab dengan frekuensi kadang. Hal ini perlu untuk diperbaiki supaya koordinasi di rumah sakit menjadi lebih baik.Pertemuan berkala antarunit ini merupakan sarana penting dalam bertukar informasi mengenai perkembangan pelaksanaan pelayanan medik di rumah sakit dan informasi perkembangan kebijakan rumah sakit terkait pelaksanaan pelayanan medik.

\section{DAFTAR PUSTAKA}

Aisul M, Abdu Naf'an.(2011). Optimalisasi Fungsi Koordinasi Program Pencegahan dan Pengendalian Infeksi Nosokomial di RSU Haji Surabaya.Skripsi.Surabaya : Universitas Airlangga, Fakultas Kesehatan Masyarakat.

Daft, Richard L.(2013). Organization Theory \& Design. Vanderbilt Univerity. United State of America.

Gittel, J.H, \&Seidner, R.(2006).Coordinating patient care: a social capital model of high performance work systems, Working paper and presentation on HRM and Knowledge Related PerformanceCopenhagenBusiness
School,Center for Strategic Management and Globalization.

Gittel, J.H.(2010). Relational coordination : Guidelines for theory, measurement and analysis, Brendeis University, Massachusetts.

Gittel, J.H, Seidner, R, \& Wimbushs, J (2010). A relational model of how high-performance work systems work, JurnalOrganization Science,Vol.21(2): 490-506.

Hakim, Lukman.(2014). Optimalisasi Proses Koordinasi Program Keselamatan Pasien (Patient Safety) di Rumah Sakit Umum Haji Surabaya.Skripsi.Surabaya : Universitas Airlangga, Fakultas Kesehatan Masyarakat.

Lemieux, Victoria. (2000). Applying Mintzberg's theories on Organizational Configuration to Archival Appraisal.The Journal of the Association of Canadian Archivists.http://journals.sfu.ca/archivar/index.p hp/archivaria/article/view/12675.

Mintzberg, Henry. (1998). The Strategy Process, consepts, context,cases. Edisi ketiga,McGill University, United States of America.

Sari, Intan P.(2015) Optimalisasi Fungsi Koordinasi Antarunit Kerja Terkait Pelaksanaan Pelayanan Medik di Rumah Sakit Bedah Surabaya.Skripsi.Surabaya : Universitas Airlangga, Fakultas Kesehatan Masyarakat.

Undang-Undang Republik Indonesia Nomor 44 tahun 2009 tentang Rumah Sakit 